\title{
Nitrate reductase activity: A solution to nitrate problems tested in free and Immobilized algal cells in presence of heavy metals
}

\author{
${ }^{*}$ M. Awasthi \\ Department of Zoology, Arunachal University, Itanagar, India
}

Received 5 July 2005;

revised 22 July 2005;

accepted 5 August 2005;

onlined 30 September 2005

\begin{abstract}
Every organism has different potential to accumulate $\mathrm{NO}_{3}$ - from the environment. Nitrate reduction processes are perhaps most significant in maintaining water quality by alteration of nitrate to nitrite. A comparative study between the nitrate reductase NR activity of green and blue green algae in presence of heavy metals is being conducted to present a situation where nitrate reductase process may be affected in presence of heavy metals. Metals interacted negatively with the nitrate reductase activity of a blue green alga, Anacystis nidulans and green algae, Chlorella vulgaris in both free and immobilized state. The activity was more repressed in C. vulgaris in presence of Ni compared to Zn and Cd. However, Cd was more toxic to NR activity in A. nidulans (free state). Metal dependent variation between free and immobilized cells were found to be significant $(\mathrm{P}<0.01)$ however, the concentration dependent pattern in the activity between free and immobilized state was non significant in both the test organisms. C.vulgaris is more efficient in conversion of nitrate to nitrite compared to A.nidulans in presence of heavy metals.
\end{abstract}

Key Words: Chlorella. vulgaris, heavy metals, anacystis nidulans, immobilization, nitrate reductase

*E-mail: awasthi6@rediffmail.com

\section{Introduction}

Nitrate is currently one of the most hazardous pollutant (Awasthi and Rai; 2005, Bier, 2002; Johnson and Kross, 1990; USEPA, 1987). NR is an enzyme that is being used to help clean up the environment, by conversion of nitrate to nitrite and has great potential to be part of the solution to the global problem of excess nitrate and related nitrogen nutrients in water sources (Campbell and Campbell, 1998). Nitrate reduction processes are perhaps most significant in maintaining water quality. NR protein is responsible not only for nitrate reduction, but also for nitrate uptake in Chlamydomonas, Chlorella sorokiniana (Knobloch and Tischner, 1989; Nichols, et al., 1978). Assimilatory $\mathrm{N}$ reduction, performed by a variety of bacterial and eukaryotic organisms (Zvyagil'skaya, et al., 1996; Solomonson and Barber, 1990) includes the reduction of nitrate and nitrite compounds, often mediated by nitrate or nitrite reductase enzymes, for synthesis of amino acids. Nitrate reductase (NR) activity is the limiting factor when considering the growth and protein production of algae (Lau et al., 1998). There is substantial concern about the growing levels of heavy metals in the environment and the detrimental effects of these elements on living organisms. Toxicity of metals on algae has been reviewed earlier (Awasthi and Das, 2005; Demon, et al., 1988; Vyamazal, 1987) confirming the deleterious effect of metals to biological macromolecules. Besides other toxic effects, $\mathrm{Ni}, \mathrm{Zn}, \mathrm{Cd}$, are also toxic to nitrate reductase activity of algal cells (Tripathy, et al., 2004). Immobilization of algal cells is of interest because it paves the way for the immobilization of the higher plant cells and provide excellent model for studying the effects of immobilization on cell physiology. Though cells in free suspension can produce valuable information in laboratory experiments, immobilized cells are advantageous for industrial scale studies. However, comparative studies on free and immobilized are meager regarding physiological and biochemical behavior of algae subjected to metal stress.

Since heavy metals and nitrate are both harmful pollutant and often occur together, it is necessary to know the effect of heavy metals on the enzyme activity more so when NR in immobilized algae can be used to treat the nutrient pollution. The biological treatment system will definitely be affected when heavy metals are present besides $\mathrm{NO}_{3}^{-}$. Although some reports are available regarding the nitrate reductase activity of algal cells in the free state however only scant information is available about the influence of these metals on the immobilized state. A comparison between different algal organism is felt necessary since each organism has different potential to accumulate $\mathrm{NO}_{3}{ }^{-}$from the 
environment due to variation in NR characteristics (Berges, 1997).

The Present study deals with the comparative account of free and immobilized green algae, $C$. vulgaris and cyanobacteria, $A$. nidulans cells regarding NR activity. It also deals with the relative toxicity of one metal compared to the others.

\section{Materials and Methods}

The organisms used in the present study are the unicellular green alga Chlorella vulgaris and blue green algae, Anacystis nidulans (Both local strain, $\mathrm{BHU}$ ). The growth medium for $C$. vulgaris (Chu10, Gerloff, et al., 1950, pH 6.8) and A. nidulans was prepared using double-distilled water, filtered and sterilized. The standard microbial techniques were employed for selection, isolation and cloning of algae in pure culture. The percent survival of the organisms was scored by the plate colony count method to obtain $\mathrm{LC}_{50}$ dose of $\mathrm{Ni}, \mathrm{Zn}$ and $\mathrm{Cd}$. The concentrations of test metals used for $C$. vulgaris were $\mathrm{Ni}: 3.20 \mu \mathrm{mol} / \mathrm{l}, 4.20 \mu \mathrm{mol} / \mathrm{l}\left(\mathrm{LC}_{50}\right)$, and 5.20 $\mu \mathrm{mol} / \mathrm{l}, \mathrm{Zn}: 0.75 \mu \mathrm{mol} / \mathrm{l}, 1.75 \mu \mathrm{mol} / \mathrm{l}\left(\mathrm{LC}_{50}\right)$, and 2.75 $\mu \mathrm{mol} / \mathrm{l}, \mathrm{Cd}: 0.16 \mu \mathrm{mol} / \mathrm{l}, 1.16 \mu \mathrm{mol} / \mathrm{l}\left(\mathrm{LC}_{50}\right)$, and 2.16 $\mu \mathrm{mol} / \mathrm{l}$, And for A.nidulans the concentrations were, $\mathrm{Ni}: 0.26 \mu \mathrm{mol} / \mathrm{l}, 1.26 \mu \mathrm{mol} / \mathrm{l}\left(\mathrm{LC}_{50}\right)$, and $2.26 \mu \mathrm{mol} / \mathrm{l}$ Zn: $3.16 \mu \mathrm{mol} / \mathrm{l}, 4.16 \mu \mathrm{mol} / \mathrm{l}\left(\mathrm{LC}_{50}\right)$, and $5.16 \mu \mathrm{mol} / \mathrm{l}$ Cd: $4.84 \mu \mathrm{mol} / \mathrm{l}, 5.84 \mu \mathrm{mol} / \mathrm{l}\left(\mathrm{LC}_{50}\right)$, and $6.84 \mu \mathrm{mol} / \mathrm{l}$

Experiments were conducted with $200 \mathrm{ml}$. cultures gently shaken at a temperature of $25 \pm 1$ ${ }^{\circ} \mathrm{C}$ with a light flux of $14.4 \mathrm{Wm}^{-2}$ (18/6 h. light per dark cycle). The cultures were aerated with $2 \%$ $\mathrm{CO}_{2}$ in air at a flow rate of approximately $1.5 \mathrm{ml} / \mathrm{ml}$ culture/min. Exponential phase free and immobilized cells were fixed to a final density of $500 \mu$ g protein per ml. Stock solutions of $\mathrm{NiCl}_{2} \cdot 6 \mathrm{H}_{2} \mathrm{O}, \mathrm{ZnSO}_{4} \cdot 7 \mathrm{H}_{2} \mathrm{O}$ and $\mathrm{CdSO}_{4} \cdot \mathrm{H}_{2} \mathrm{O}$ were sterilized by passing through Millipore membrane filters $(0.45 \mu \mathrm{m}$.) before adding to the culture medium. Biochemical's used were obtained from Sigma chemical company, MO, USA and $\mathrm{BDH}$, UK.

\section{Cell immobilization}

Exponentially grown algal cells obtained by centrifugation and repeated washings, were suspended in $5 \%(\mathrm{w} / \mathrm{v})$ solution of sodium alginate (Sigma). The mixture was pumped drop-wise into $\mathrm{CaCl}_{2}(0.2 \mathrm{~mol} / \mathrm{l})$ solution, and the beads thus formed (with an average diameter of $5 \mathrm{~mm}$. and allowed to harden for $2 \mathrm{~h}$.) were washed several times with sterile double-distilled water and re-suspended in a $200 \mathrm{ml}$ growth medium for autotrophic growth under culture-room conditions along with the free cells. Percent inhibition was calculated (in both free and immobilized cells) by considering the untreated cells in the free state as control. Protein was estimated following the method of Herbert et al., (1971).

\section{Nitrate reductase activity}

The estimation of NR activity was done following the method of Camm and Stein (1974). The activity is based on the total nitrite formed. For the estimation of enzyme activity known amount of algal suspension was centrifuged and washed 3-4 times with sterile double distilled water and suspended in culture medium containing $5 \mathrm{mM} \mathrm{NaNO}$. For different intervals, different sets of culture tubes containing 1 $\mathrm{ml}$ of culture (final) were incubated. Standard curve was plotted with varying concentrations of $\mathrm{NaNO}_{3}$ dissolved in test medium. The metal treatment experiments involved in the supplementation of $\mathrm{Ni}$, $\mathrm{Zn}$ and $\mathrm{Cd}$ at graded concentration. The absorbance of pink color was measured at $540 \mathrm{~nm}$.

\section{Release of immobilized cells}

The assays were determined by dissolving the solid matrix (alginate beads). Matrices of calcium alginate can be readily dissolved by exposure to hexametaphosphate (Bozeman, et al., 1989).

\section{Statistical treatment}

Values presented are the means of five independent experiments with the bar showing standard deviation in each case. The data for various metal treatments were verified for their significance at a particular probability level, and the variance ratio (F) calculated as $F=T / R$, where $T$ is treatment mean square, and $\mathrm{R}$ residual mean square. The components for ANOVA (3-way) were metal type (Ni, Zn, Cd); cell state type (free and immobilized) and metal treatment (non-inhibitory, 50\% inhibitory and more than $50 \%$ inhibitory).

\section{Results}

A decrease in the activity of nitrate reductase was noticed with increase in metal concentration in both C. vulgaris (Table 1 ) and A. nidulans (Fig. 1). $\mathrm{LC}_{50}$ concentrations of $\mathrm{Ni}, \mathrm{Zn}$ and $\mathrm{Cd}$, inhibited the nitrate reductase activity by 87.2, 50.0, 72.1 and $53.6,34.6,38.0 \%$ respectively in free and immobilized C. vulgaris. $100 \%$ activity ( $0 \%$ inhibition) in Anacystis nidulans as shown in Fig. 2 is equal to $116 \mathrm{ng} \mathrm{NO}_{2}^{-} \mu \mathrm{g}$ /protein (free cells). Fig. 2 also reveals more pronounced activity by immobilized cells. 
Table 1: Impact of Ni, Zn and Cd on nitrate reductase activity (after $72 \mathrm{~h}$.) of free and immobilized Chlorella vulgaris

\begin{tabular}{|cccc|}
\hline \multirow{2}{*}{ Metal concentration $(\mu \mathrm{mol} / \mathrm{l})$} & \multicolumn{2}{c|}{$\begin{array}{c}\text { Nitrate-reductase activity }\left(\mathrm{ng} \mathrm{NO}_{2}{ }^{-} \mu \mathrm{\mu g} / \mathrm{protein}\right) \\
\text { Free living }\end{array}$} \\
\hline \multirow{4}{*}{$\mathrm{Ni}$} & Control & $98.84 \pm 0.03$ & $120.00 \pm 0.04(21.4)^{*}$ \\
& 3.20 & $40.52 \pm 0.02(59.0)$ & $56.80 \pm 0.04(42.5)$ \\
& 4.20 & $12.65 \pm 0.03(87.2)$ & $45.80 \pm 0.09(53.6)$ \\
$\mathrm{Zn}$ & 5.20 & $9.88 \pm 0.04(90.0)$ & $31.40 \pm 0.06(68.2)$ \\
& 0.75 & $59.30 \pm 0.04(40.0)$ & $64.60 \pm 0.03(34.6)$ \\
& 1.75 & $49.42 \pm 0.04(50.0)$ & $60.90 \pm 0.04(38.3)$ \\
$\mathrm{Cd}$ & 2.75 & $24.71 \pm 0.03(75.0)$ & $35.40 \pm 0.05(64.1)$ \\
& 0.16 & $35.00 \pm 0.02(64.0)$ & $65.00 \pm 0.07(35.1)$ \\
& 1.16 & $27.50 \pm 0.05(72.1)$ & $61.20 \pm 0.07(38.0)$ \\
\hline
\end{tabular}

All the values are mean \pm SE

* Sign shows stimulation over control (free cells)

Data in parentheses denote \% inhibition. All the treatments are significantly different $(\mathrm{P}<0.005)$ from their respective control according to students ' $\mathrm{t}$ ' test

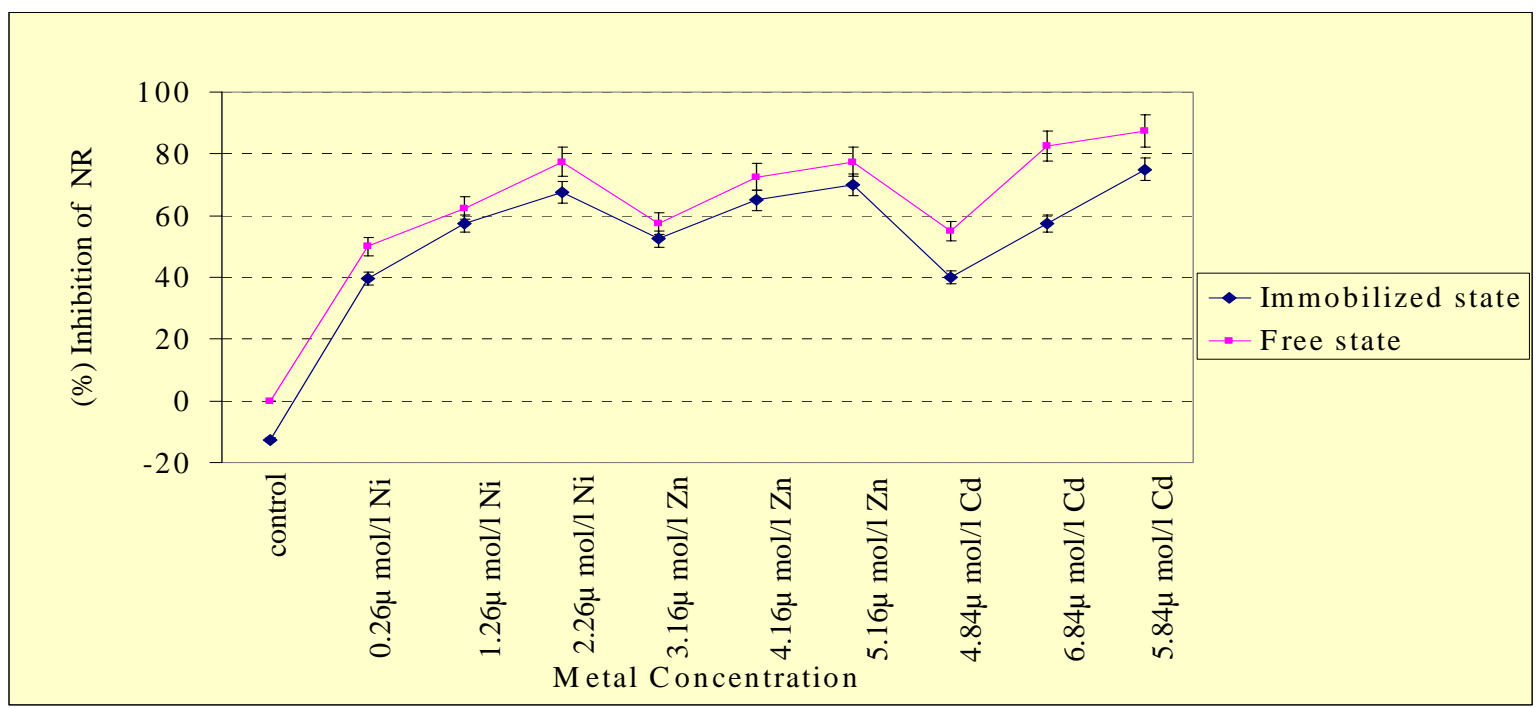

Fig. 1: Pattern of metal concentration dependent inhibition of nitrate reductase activity in anacystis nidulans in free and immobilized states

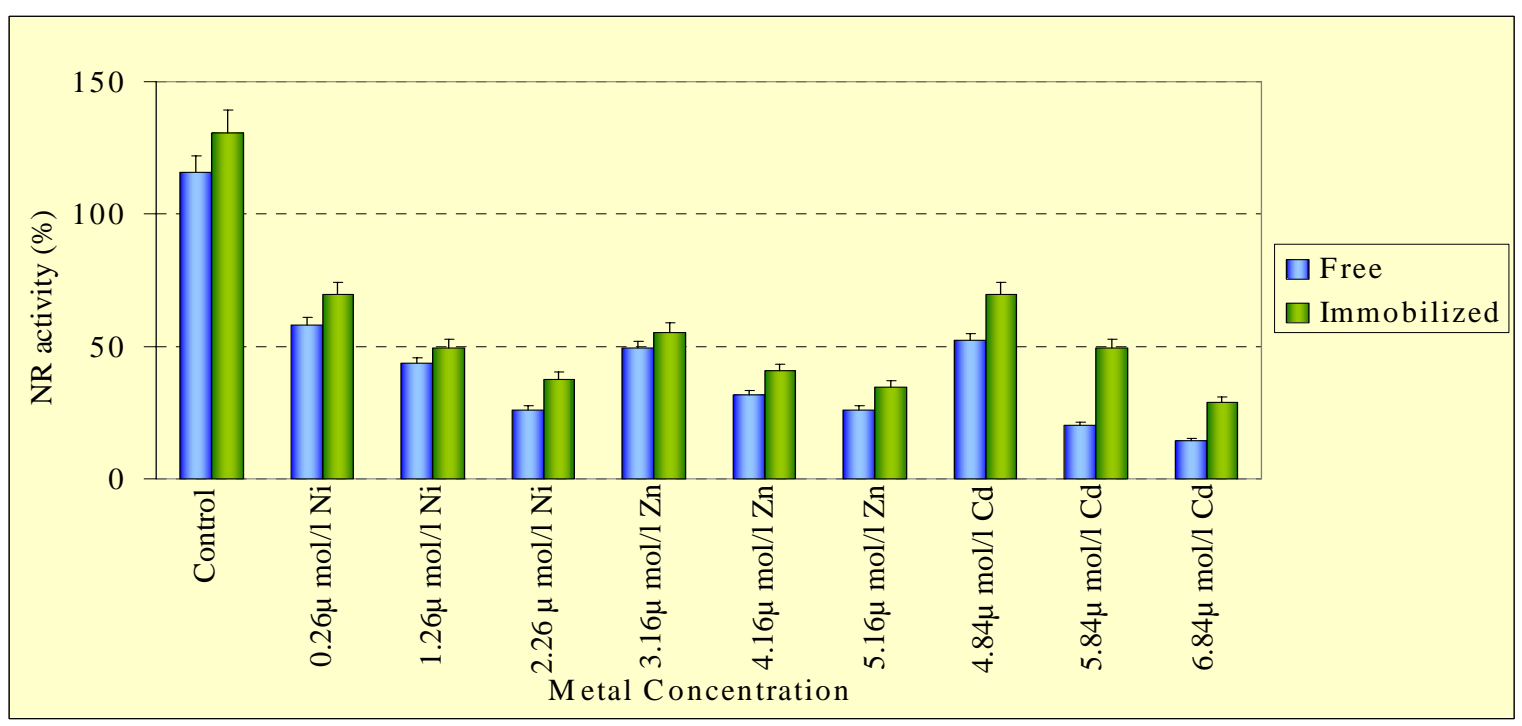

Fig. 2: Effect of different concentrations of heavy metals on nitrate reductase activity of anacystis nidulansin free and immobilized states 
Table 2: Analysis of variance (3-way) table for nitrate reductase activity of Chlorella vulgaris

\begin{tabular}{|lccccc|}
\hline Source of variation & $\begin{array}{c}\text { Degree of } \\
\text { freedom }\end{array}$ & Sum of squares & Mean square & F-value & $\begin{array}{c}\text { Significance } \\
\text { level }\end{array}$ \\
\hline A & 1 & 2620.87 & 2620.87 & 288.28 & $\mathrm{P}<0.001$ \\
Metal & 3 & 21947.97 & 7315.99 & 804.73 & $\mathrm{P}<0.001$ \\
Conc. & 3 & 1722.67 & 861.33 & 94.74 & $\mathrm{P}<0.001$ \\
A x metal & 3 & 332.70 & 110.90 & 12.19 & $\mathrm{P}<0.01$ \\
A x conc. & 3 & 49.46 & 24.73 & 2.72 & $\mathrm{P}>0.05$ \\
Metal x conc. & 9 & 773.63 & 128.93 & 14.18 & $\mathrm{P}<0.01$ \\
Error & 9 & 34.54 & 9.90 & & \\
\hline Total & 31 & & & 27501.86 & \\
\hline
\end{tabular}

$\mathrm{A}=$ Cell type (free and immobilized cells)

Metals $=\mathrm{Ni}, \mathrm{Zn}, \mathrm{Cd}$

Conc. $=$ Concentration of metals (Non-inhibitory, $50 \%$ inhibitory level, inhibitory level)

Table 3: Analysis of variance (3-way) table for nitrate reductase activity of Anacystis nidulans

\begin{tabular}{|lccccc|}
\hline $\begin{array}{l}\text { Source of } \\
\text { variation }\end{array}$ & $\begin{array}{c}\text { Degree of } \\
\text { freedom }\end{array}$ & Sum of squares & Mean square & F-value & $\begin{array}{c}\text { Significance } \\
\text { level }\end{array}$ \\
\hline A & 1 & 853.53 & 853.53 & 116.15 & $\mathrm{P}<0.001$ \\
Metal & 3 & 31178.76 & 10392.92 & 1415.95 & $\mathrm{P}<0.001$ \\
Conc. & 3 & 2394.93 & 1197.46 & 163.14 & $\mathrm{P}<0.001$ \\
A x Metal & 3 & 113.67 & 37.89 & 5.16 & $\mathrm{P}<0.05$ \\
A x Conc. & 3 & 15.09 & 7.54 & 1.02 & $\mathrm{P}>0.05$ \\
Metal x Conc. & 9 & 1039.31 & 173.21 & 23.59 & $\mathrm{P}<0.01$ \\
Error & 9 & 44.03 & 7.33 & & \\
\hline Total & 31 & & 35638.35 & & \\
\hline
\end{tabular}

$\mathrm{A}=$ Cell type (free and immobilized cells)

Metals $=\mathrm{Ni}, \mathrm{Zn}$, Cd

Conc. $=$ Concentration of metals (Non-inhibitory, 50\% inhibitory level, inhibitory level)

62.5, 72.5, 82.5 and 57.5, 65.0 and $57.5 \%$ inhibition in NR activity of free and immobilized cells of $A$. nidulans as obvious from Fig. 1 . The nickel toxicity to the activity was higher in $C$. vulgaris compared to $A$. nidulans which is in contrast to immobilized cells where the Ni toxicity was more to $A$. nidulans. However, zinc and cadmium were more toxic to $A$. nidulans than $C$. vulgaris, both in free and immobilized conditions.

Tables 2 and 3 represent the statistical analysis of the results found in $C$. vulgaris and $A$. nidulans respectively. A significant decrease ('t' significant at $\mathrm{P}<0.005$ ) in the NR activity following metal treatment has been observed in both free and immobilized state. The efficiency of nitrite production in the immobilized (untreated) cells was 1.21 and 1.15 fold higher (ANOVA significant at $\mathrm{P}<0.05$ ) compared to free suspension of $C$. vulgaris and $A$. nidulans respectively. Although, on treatment with $\mathrm{LC}_{50}$ dose of $\mathrm{Ni}, \mathrm{Zn}$ and $\mathrm{Cd}$, the immobilized cells depicted 3.6, 1.2 and 2.2 fold increase $(\mathrm{P}<0.005)$ for $C$. vulgaris and 1.04, 1.18, 1.44 fold increase $(\mathrm{P}<0.005)$ for $A$. nidulans in nitrite production. Metal dependent variation between free and immobilized cells were found to be significant $(\mathrm{P}<0.01)$ and $A$. nidulans $(\mathrm{P}<0.005)$ however, the concentration dependent pattern in the activity between free and immobilized state was non significant $(\mathrm{P}<0.05$, ANOVA).

\section{Discussion and Conclusion}

Uptake of metals and metalloids can be harmless (i.e., no effects), toxic or even beneficial. Experiments on NR activity revealed that $\mathrm{Ni}, \mathrm{Zn}$ and Cd inhibit the synthesis of NR. The displacement of an essential metal ion forming the central and functional part of the enzyme protein may be one of the reasons for inhibition of nitrate reductase by heavy metals and secondly, interference with sulphydryl (-SH) groups which often determine the secondary and tertiary structure of proteins. Besides, a reduced energy supply due to the inhibition of ${ }^{14} \mathrm{CO}_{2}$ incorporation, photosynthetic electron transport and an indirect inhibition of uptake of substrate $\left(\mathrm{NO}_{3}{ }^{-}\right)$of enzyme may be other important reason. Yet, a less pronounced inhibition of enzymatic activities of immobilized cells as compared to free suspension could be ascribed to the operation of an efficient energy generation process in the immobilized state. Immobilization allows the cells to 
grow in close physical association with each other, and together with the slow growth, it results in chemical and physical communication between cells. Besides, any stimulation in the ATP pool and availability of NADPH may stimulate ATP dependent processes like, NR activity. Thus enhanced photosynthetic activity indicates towards increase of the enzymatic activities. $C$. vulgaris is more efficient in nitrite production compared to $A$. nidulans and thus recommends the use of green algae compared to cyanobacteria in vitro condition until any other blue green algae is found which is equally/more efficient in removing the nitrate from the environment especially in presence of heavy metals like $\mathrm{Ni}$ and $\mathrm{Cd}$.

As a result, the following inferences is concluded from the present study:

- Ni toxicity was higher in $C$. vulgaris compared to $A$. nidulans which is in contrast to immobilized cells where the Ni toxicity was more to $A$.

- $\mathrm{Zn}$ and $\mathrm{Cd}$ were more toxic to $A$. nidulans than C. vulgaris, both in free and immobilized conditions.

- The efficiency of nitrite production in the immobilized (untreated) cells was 1.21 and 1.15 fold higher compared to free suspension of $C$. vulgaris and $A$. nidulans respectively.

- On treatment with $\mathrm{LC}_{50}$ dose of $\mathrm{Ni}, \mathrm{Zn}$ and $\mathrm{Cd}$, the immobilized cells depicted 3.6, 1.2 and 2.2 fold increase $(\mathrm{P}<0.005)$ for $C$. vulgaris and 1.04, 1.18, 1.44 fold increase $(\mathrm{P}<0.005)$ for $A$. nidulans in nitrite production.

\section{Acknowledgement}

Thanks are due to Council of Scientific and Industrial Research, New Delhi for post-doctoral fellowship.

\section{References}

Awasthi M. and Das D. N., (2005). Impact of Ni, Zn and $C d$ on growth rate, photosynthetic activity, nitrate reductase and alkaline phosphatase activity of free and immobilized Scenedesmus quadricauda. Algol. Studies, 115, 53-64.

Awasthi M. and Rai L. C., (2005). Toxicity of Nickel, Zinc and Cadmium to nitrate uptake in free and immobilized cells of Scenedesmus quadricauda. Ecotox. Environ. Safe., 61, 268-272.

Berges J. A., (1997). Miniview: Algal nitrate reductases. Eur. J. Phycol., 32, 3-8.

Bier J., (2002). Nitrate in groundwater: Sources, Impacts and Solutions. $6^{\text {th. }}$ Symposium on Groundwater contaminants, Nov $12^{\text {th. }}$ and $13^{\text {th. }}$ Fresno, CA.

Bozeman J., Koopman B., and Bitton G., (1989). Toxicity testing using immobilized algae. Aqua. Toxic., 14, 345-352.

Campbell E. R. and Campbell W. H., (1998). Determination of nitrate in aqueous matrices using nitrate reductase. In: Current protocols in field analytical chemistry, supplement 1, Chapter 5 "Water Quality Parameters-Anions”, John Wiley and Sons, Inc.

Camm E. L. and Stein J. R., (1974). Some aspects of nitrogen metabolism of Nodularia spuigena (Cyanophyceae), Can. J. Bot., 52, 719-726.

Demon A., De Bruin M. and Wolterbeck H. T., (1988). The influence of $\mathrm{pH}$ on trace metal uptake by an alga (Scenedesmus pannonicus Subsp. Berlin) and fungus (Aureobasidium pullulans). Environ. Monitor. Assess., 10, 165-173.

Gerloff G. C., Fitzerald G. P. and Skoog F., (1950). The isolation, purifica-tion, and culture of blue-green algae. Am. J. Bot., 27, 216-218.

Herbert D., Phipps P. J. and Strange R. E., (1971). Chemical analysis of microbial cells. In: Norris, $J R$ and Ribbons, D W (Ed.): Methods in Microbiology, Academic Press, London, 209-334.

Johnson C. J and Kross B. C., (1990). Continuing importance of nitrate contamination of groundwater and wells in rural areas, Am. J. Int Med., 18, 449-456.

Knobloch O. and Tischner R., (1989). Characterization of nitrate reductase deficient mutants of Chlorella sorokiniana. Plant Physiol. 89, 786-791.

Lau P. S., Tam N. F. Y. and Wong Y. S., (1998). Effect of carrageenan immobilization on the growth, physiology and nitrate reductase activity of Chlorella vulgaris. Bioresource Technol., 63, 115-121.

Nichols G. L., Shehata S. A. M. and Syrett P. J., (1978). Nitrate reductase deficient mutants of Chlamydomonas reinhardii: Biochemical characteristics. J. Gen. Microbiol. 108, 79-88.

Solomonson L. P. and Barber M. J., (1990). Assimilatory nitrate reductase: functional properties and regulation. Plant Mol. Biol., 41: 225-253.

Tripathi B. N., Mehta S. K. and Gaur J. P., (2004). Recovery of uptake and assimilation of nitrate in Scenedesmus sp. previously exposed to elevated levels 
M. Awashti

of Cu2+ and Zn2+. J Plant Physiol. 161, 543-549.

US Environmental Protection Agency, (1987). Nitrate/ nitrite health advisory. Washington: US Environmental Protection Agency, Office of Drinking Water.
Vyamazal J. C., (1987). Toxicity and accumulation of cadmium with respect to algae and cyanobacteria; $A$ review. Toxicity Assess., 2, 387-415.

Zvyagil'skaya R. A., Vartapetyan B. B. and Vov N. P. L, (1996). Nitrate dissimilation in eukaryotes. Appl. Biochem. Microbiol., 32, 165 -169. 